\title{
Are Down's syndrome patients a risk group for celiac disease?
}

\section{Czy pacjenci z zespołem Downa są grupą ryzyka wystąpienia celiakii?}

\author{
Aleksandra Nowak-Oczkowska1 , Anna Szaflarska-Popławska², Anetta Soroczyńska-Wrzyszcz \\ 1Department and Clinic of Pediatrics, Allergology, and Gastroenterology, Nicolaus Copernicus University, Ludwik Rydygier \\ Collegium Medicum, Bydgoszcz, Poland \\ 2Department of Pediatric Endoscopy and Gastrointestinal Function, Nicolaus Copernicus University, Ludwik Rydygier \\ Collegium Medicum, Bydgoszcz, Poland \\ ${ }_{3}^{3}$ Department of Pediatric Endocrinology, Cardiology and Neurology for Children and Adolescents, Regional Specialist Hospital, \\ Grudziadz, Poland
}

Prz Gastroenterol 2013, 8 (2): 77-85

DOI: $10.5114 /$ pg.2013.34832

Key words: celiac disease, Down's syndrome, incidence, screening.

Słowa kluczowe: choroba trzewna, zespół Downa, częstość występowania, badania przesiewowe.

Address for correspondence: Department and Clinic of Pediatrics, Allergology, and Gastroenterology, Ludwik Rydygier Collegium Medicum, Nicolaus Copernicus University, 9 Marii Skłodowskiej-Curie, 85-094 Bydgoszcz, Poland, phone: +48 5258548 50, fax: +48 525854086 , e-mail: klped@cm.umk.pl

\begin{abstract}
Celiac disease is a genetically determined enteropathy caused by permanent gluten intolerance. The factors considered as responsible for celiac disease are genetic and environmental factors, as well as auto-immunological processes which lead to chronic inflammation. There are reports in the literature that indicate co-occurrence of celiac disease with many diseases, and one of the reported risk groups of celiac disease is patients with the most frequent chromosome abnormality Down's syndrome. Many societies and authors recommend screening of this group.
\end{abstract}

\section{Introduction}

Celiac disease is a permanent gluten intolerance causing small intestine enteropathy of an auto-immunological background, in patients with a genetic predisposition. The factors causing the disease are prolamins contained in wheat (gliadin), rye (secalin), and barley (hordein). The role of avenin contained in oat remains controversial; however, due to technical difficulties in obtaining a clean form of this cereal in Polish conditions, products containing oats are considered as containing gluten and only an oat-free diet is considered as gluten-free [1]. Celiac disease can develop at any age after introduction of gluten

\section{Streszczenie}

Celiakia jest genetycznie uwarunkowaną enteropatią spowodowaną trwałą nietolerancją glutenu. Wśród czynników odpowiedzialnych za ujawnienie choroby trzewnej wymienia się czynniki genetyczne, środowiskowe oraz procesy autoimmunologiczne prowadzące do przewlekłych stanów zapalnych. W piśmiennictwie opisuje się wspótistnienie choroby trzewnej z wieloma jednostkami chorobowymi, a za jedną z grup ryzyka rozwoju celiakii uznaje się najczęstszą aberrację chromosomalną, jaką jest zespół Downa. Wiele towarzystw i autorów rekomenduje przeprowadzanie badań przesiewowych w tej grupie pacjentów.

into the diet. The manifestation of the classic form of the disease involves typical signs of malabsorption (insufficient weight and height, chronic diarrhea, steatorrhea). Due to the variety of the clinical picture of celiac disease, and sometimes its non-classical, or asymptomatic course, there are a few clinical forms of the disease:

1) classical (typical) celiac disease mentioned before dominant are the symptoms in the gastrointestinal tract, serological markers are found, small intestine biopsy shows atrophy of intestinal villi;

2) non-classical celiac disease - dominant are nonintestinal symptoms, symptoms in the gastrointesti- 
nal tract are mild, serological markers are found, small intestine biopsy shows atrophy of intestinal villi;

3) silent celiac disease - asymptomatic course, serological markers are found, small intestine biopsy shows atrophy of intestinal villi (which is found during endoscopic examination performed due to other recommendations or as part of screening of risk groups). Despite the lack of clinical symptoms, the silent form of celiac disease should be treated, because of a higher incidence of auto-immunological diseases and lymphomas in the gastrointestinal tract in this group of patients;

4) latent celiac disease - asymptomatic course, serological markers are found, small intestine biopsy shows normal mucous membrane when a diet containing gluten is applied, gluten-dependent enteropathy can occur later on [according to 2].

Currently, the gold standard of celiac disease diagnostics in children is still biopsy of the small intestine mucous membrane and its histopathological analysis, according to Marsh's scale modified by Oberhuber [3]. The procedure involves assessment of a few biopsy specimens from the mucous membrane of different parts of the duodenum. Serological markers of celiac disease, including anti-endomysium antibodies (EmA) and antibodies against tissue transglutaminase (tTG), are crucial in diagnostics, screening, and assessment whether the gluten-free diet is observed. ESPGHAN (the European Society for Paediatric Gastroenterology, Hepatology and Nutrition) proposed new criteria of celiac disease diagnostics, which allow the small intestine biopsy to be avoided in children and adolescents showing signs suggesting celiac disease [4].

Improvement of the clinical picture of celiac disease is observed after application of a gluten-free diet, which is the principle of treatment and is continued for the rest of the patient's life [1, 2].

Many authors observe co-occurrence of celiac disease with auto-immunological diseases or genetic syndromes. One of the risk groups is patients with Down's syndrome. This syndrome is the most frequent chromosome abnormality and at the same time the main genetic factor causing mental retardation. For many years, reports in the literature have recommended screening of pediatric and adult Down's syndrome patients. However, these recommendations are mainly based on results of studies performed on patient groups which were too small and too variable in terms of the applied criteria of celiac disease diagnostics.

\section{Frequency of celiac disease in the general population}

Until the 1980s, celiac disease was considered a rare disorder. However, in the next years, it was reported that its incidence was more frequent than initially supposed. Epidemiological studies on the incidence of celiac disease in the general population differ depending on the geographical region, race, studied group, group size, and environmental factors [5-8]. Most patients with celiac disease, especially in its non-classical or silent forms, remain undiagnosed, and therefore the epidemiological data are only approximate, and their interpretation and comparison are difficult. In most countries, there are no registers of celiac disease patients, so the total number of patients is unknown. It makes some authors wonder whether it is necessary to conduct screening of large groups of patients $[6,9,10]$.

In a systematic review, Dube et al. [6] estimated the incidence of celiac disease in the general population of Western countries at $1 \%(1: 100)$. The range of celiac disease incidence in the Western European and North American populations, according to different authors, was between $0.5 \%$ and $1.26 \%$ ( $1: 200$ to $1: 79)$. Higher incidence of celiac disease (from $1 \%$ to $1.5 \%$ ) was found in some North European countries [6]. In pediatric populations the incidence of celiac disease was estimated at $0.31 \%$ to $0.94 \%$ [6]. According to Biagi et al. [7], based on the most recent systematic review of literature data, the incidence of celiac disease in the general population seems to be lower than Dube et al. estimated [6] and is $6.2 \%$ o $(1: 160)$. According to the authors, the large discrepancy in the epidemiological data, which makes reliable determination of the incidence of celiac disease impossible, is due to different criteria used for diagnosis of the disease. It applies, in particular, to studies in which determination of the level of antibodies against tissue transglutaminase (tTG) was used as the only diagnostic test. So far, the highest percentage of pediatric patients with positive results of serological tests (EmA) was found by Catassi et al. [11], who studied a population of 989 children living in Sahrawi $(5.6 \%$ of the total population).

It is assessed that the incidence of celiac disease in Poland is similar to or slightly lower than the incidence observed in other European countries. Based on an epidemiological study performed on a large group of 3235 pediatric patients living in the area of Bydgoszcz, the incidence of celiac disease confirmed by histopathological examination was 1:404 and the frequency of positive results of serological examinations was $1: 124$ children (0.8\%) [5]. Based on approximate data from surveys coming from $40 \%$ of pediatric gastroenterological outpatient clinics in Poland, the number of pediatric patients under the care of these clinics is very low (1405 children and adolescents), which may suggest a significant number of patients with undiagnosed celiac disease [12]. We have observed that non-classical and silent 
celiac disease tend to be diagnosed more frequently in recent years in Poland [12]. Therefore, some authors wonder if it is necessary to perform screening of the general population, similarly as in the case of screenings for hypothyroidism, phenylketonuria or cystic fibrosis applied in Poland.

Apart from the unquestionable genetic factor predisposing to celiac disease, the pathogenesis of the disease is thought to involve many other factors. The environmental, triggering factor is gluten. However, other important factors increasing the incidence of celiac disease are thought to be: drugs (interferon $\alpha$ ), infections, particular dietary habits (amount and time of introduction of gluten into diet, breastfeeding), or exposure to tobacco smoke [according to 13].

Based on an analysis of the incidence of celiac disease in the pediatric population of two neighboring geographical regions, similar in terms of size and gluten consumption - Finland and the Russian Republic of Karelia - it seems that the risk of celiac disease can be influenced by the social and financial status, as well as hygienic habits [14]. Considering the higher incidence of celiac disease in Finland $(1: 107)$ and lower in Karelia ( $1: 496)$, the authors concluded that lower financial status, worse hygienic conditions, and more frequent infections can exert a protective effect against celiac disease.

Results of some studies on whole populations show that celiac disease is quite common in most populations consuming considerable amounts of gluten, which proves that particular dietary habits play a role in the pathogenesis of celiac disease [11, 15-17].

In the literature, there are a few reports showing growth in the frequency of diagnosis of celiac disease during the last 20 years, which is probably due to actual growth in the incidence of the disease, and not due to improvement in the reliability of diagnostic tests and awareness of physicians $[8,17]$.

\section{Incidence of celiac disease in risk groups}

There are reports showing a higher incidence of celiac disease in patients with particular disorders, compared to the general population. In a systemic review, researchers from Canada confirmed a higher incidence of celiac disease in particular risk groups [6]. It regarded, in particular, patients with type 1 diabetes (3-6\%), relatives of celiac disease patients (2.8-17.2\% in first-degree relatives and $2.6-19.5 \%$ in more distant relatives), patients with symptomatic (10-15\%) and asymptomatic (2.3-6\%) iron deficiency anemia, and in patients with low bone mineral density (0.9-3\%) [6]. The authors did not include in their analysis studies on the incidence of celiac disease in Down's syndrome patients.

\section{Incidence of celiac disease in Down's syndrome patients}

The first reports on co-occurrence of Down's syndrome and celiac disease were published already in the 1970s [18]. Initially, these were only case studies on individual patients. Most of the studies assessing the incidence of celiac disease in Down's syndrome patients were published in the 1990s. In the first papers on this subject, out of all serological examinations qualifying patients for small intestine biopsy, only anti-gliadin antibodies, which are not very specific and give a high percentage of falsepositive results, were taken into account. Only after some time did highly sensitive and specific anti-endomysial antibodies start being taken into account.

In the 1990s, there were two reports on the incidence of Down's syndrome in the group of celiac disease patients. In a retrospective study, Dias and Walker-Smith [19] found as much as 16-fold higher incidence of Down's syndrome among celiac disease patients $(1.6 \% ; 3 / 190)$, compared to the general population (0.1\%; 1 : 1000). Different results were obtained by Granditsch and Rossipal [20], who assessed the incidence of Down's syndrome in celiac disease patients at $0.19 \%(2 / 1033)$, which is only two times higher than in the general population (0.1\%). Although the incidence of Down's syndrome in celiac disease patients assessed in the above-mentioned studies is significantly different, both of these studies indicate a higher incidence of Down's syndrome in celiac disease patients than in the general population.

For many years Down's syndrome patients were considered by different authors as a risk group of celiac disease. The available studies results indicate a higher incidence of celiac disease in Down's syndrome patients than in the general population, though the studies were performed on groups of patients which were variable in terms of age and the applied criteria of celiac disease diagnosis; also the size of groups was small [21-46] (Table I). The authors also used different criteria of patient selection (Table II). There are no reports by Polish authors assessing the incidence of celiac disease in pediatric or adult Down's syndrome patients.

According to observations of different authors, the incidence of celiac disease in Down's syndrome patients is assessed at from 1\% [42] to even 19\% [29] (Table I). The large discrepancy in the obtained results is mostly due to the size of the studied groups. The very high incidence of celiac disease observed by some authors in Down's syndrome patients (from $10.3 \%$ to even $18.6 \%$ ) was obtained only in studies conducted on small or very small groups of patients (from 25 to 97 people) [23, 26, $29,33,39,45]$. In one of the studies, the diagnosis of 


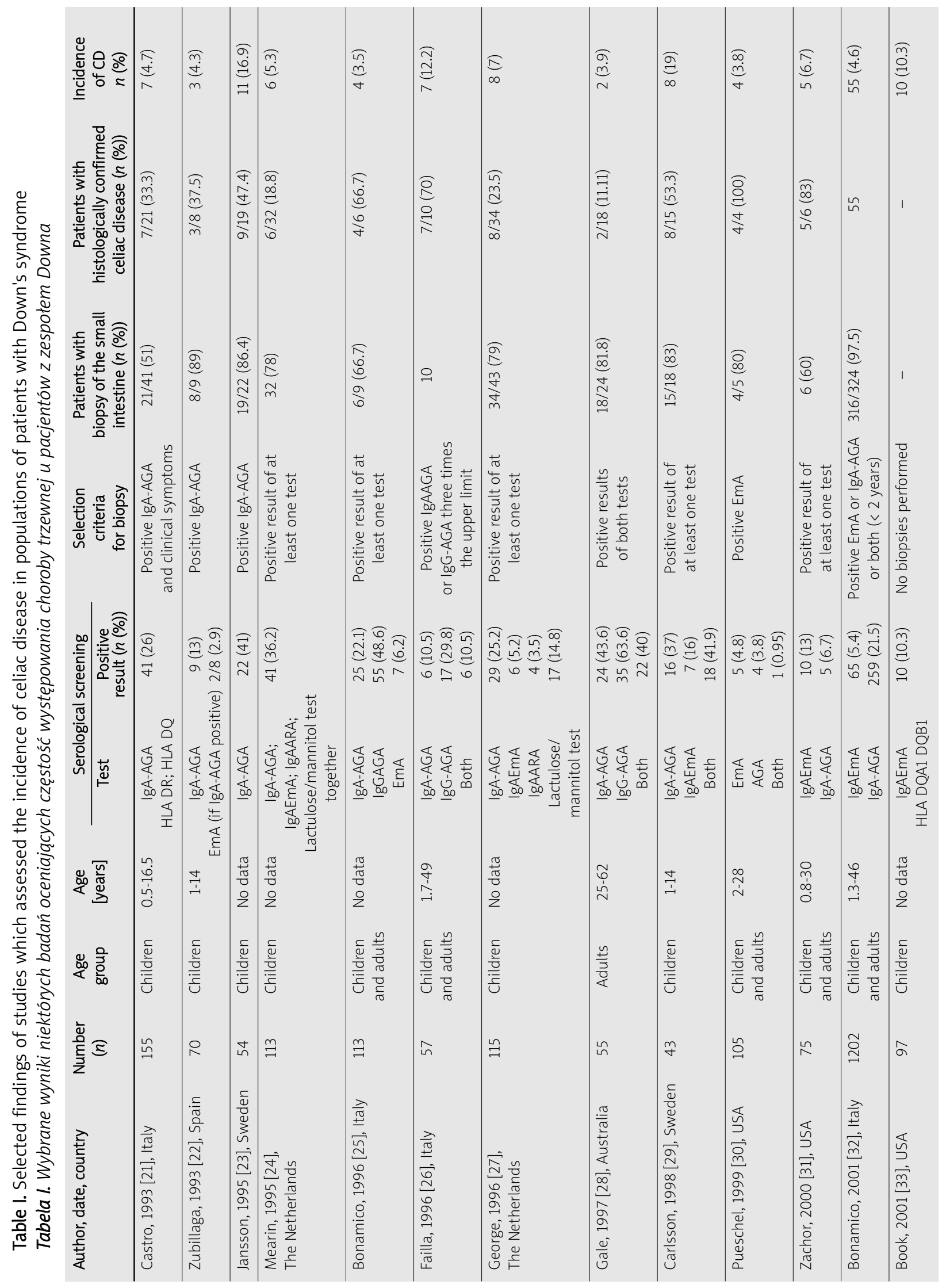




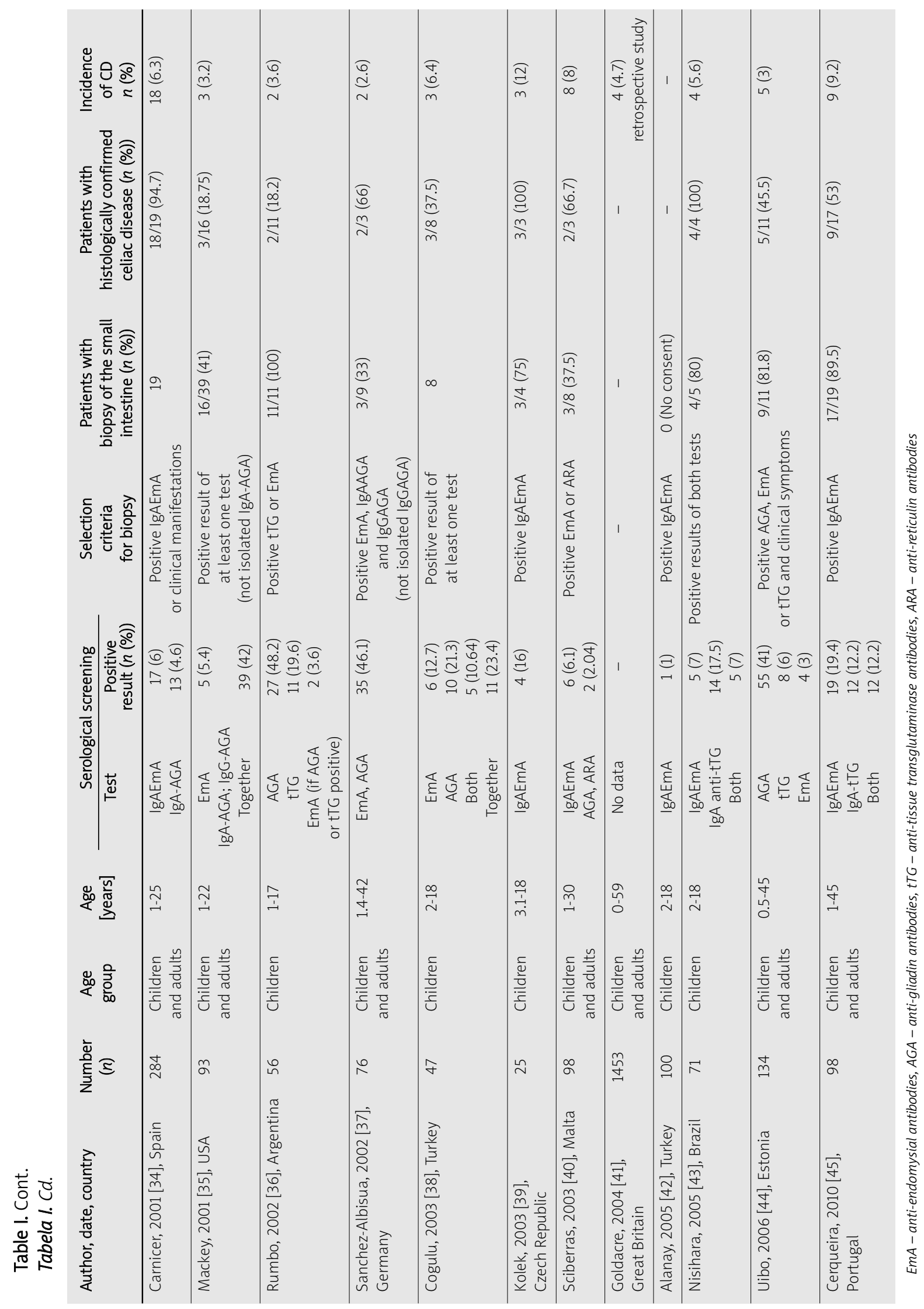


Table II. Selection criteria of patients with Down's syndrome in studies evaluating the incidence of celiac disease in this group of patients

Tabela II. Kryteria doboru pacjentów z zespołem Downa w badaniach oceniających częstość występowania celiakii $w$ tej grupie chorych

\begin{tabular}{|c|c|}
\hline Author, date, country & Selection criteria of patients with Down's syndrome \\
\hline Castro, 1993 [21], Italy & No data \\
\hline Zubillaga, 1993 [22], Spain & Patients attending a local Child Health Clinic in the north of Spain \\
\hline Jansson, 1995 [23], Sweden & Down's syndrome children in Jonkoping county in Sweden \\
\hline Mearin, 1995 [24], The Netherlands & No data \\
\hline Bonamico, 1996 [25], Italy & No data \\
\hline Failla, 1996 [26], Italy & Sicilian Down's syndrome patients \\
\hline George, 1996 [27], The Netherlands & $\begin{array}{l}\text { Patients from the database of the Dutch Down's Syndrome Foundation from the province } \\
\text { of "Zuid-Holland" }\end{array}$ \\
\hline Gale, 1997 [28], Australia & $\begin{array}{l}\text { DS patients from the largest governmental institution for people with intellectual disability } \\
\text { in New South Wales, Australia }\end{array}$ \\
\hline Carlsson, 1998 [29], Sweden & Down's syndrome children from Malmö \\
\hline Pueschel, 1999 [30], USA & Patients of the Child Development Center of Rhode Island Hospital on the East Coast of the USA \\
\hline Zachor, 2000 [31], USA & $\begin{array}{l}\text { Down's syndrome patients in the south-east part of the USA attending the Down's Syndrome } \\
\text { Clinic of The Children's Hospital of Alabama }\end{array}$ \\
\hline Bonamico, 2001 [32], Italy & Patients under care of the Italian Society of Pediatrics from various regions of Italy \\
\hline Book, 2001 [33], USA & No data \\
\hline Carnicer, 2001 [34], Spain & Patients from pediatric clinics, therapy centers, and special schools in Barcelona \\
\hline Mackey, 2001 [35], USA & Patients attending a local child health clinic \\
\hline Rumbo, 2002 [36], Argentina & Patients from the Pediatric Hospital in La Plata \\
\hline Sanchez-Albisua, 2002 [37], Germany & No data \\
\hline Cogulu, 2003 [38], Turkey & Patients from the Genetics Clinic of the University Hospital in Izmir \\
\hline Kolek, 2003 [39], Czech Republic & $\begin{array}{l}\text { Down's syndrome children living in the north of the Moravian region, from the Association } \\
\text { of DS Patients and the Department of Genetics and Fetal Medicine }\end{array}$ \\
\hline Sciberras, 2003 [40], Malta & Patients from the database of the regional St Luke's Hospital in Malta \\
\hline Goldacre, 2004 [41], Great Britain & $\begin{array}{l}\text { Medical documentation of Down's syndrome patients in the former Oxford health region } \\
\text { in England from } 1963 \text { to } 1999 \text { - a retrospective study }\end{array}$ \\
\hline Alanay, 2005 [42], Turkey & Patients attending a local child health clinic \\
\hline Nisihara, 2005 [43], Brazil & Patients attending a university health clinic \\
\hline Uibo, 2006 [44], Estonia & Patients from the Pediatric Clinic of Tartu University \\
\hline Cerqueira, 2010 [45], Portugal & Down's syndrome patients living in the north of Portugal \\
\hline Pavlovic, 2010 [46], Serbia & No data \\
\hline
\end{tabular}

celiac disease was based only on positive results of serological studies, which was inconsistent with the current diagnostic criteria and probably inflated the assessed epidemiological indexes [33]. The very high incidence of celiac disease in Down's syndrome patients (16.9\%; $19 \%$ ) reported by Swedish authors [23, 29] could have been related to the higher incidence of celiac disease in the general Swedish population $[16,17]$ and to the criteria used by the authors, which were inconsistent with the current criteria of celiac disease diagnosis.

Studies conducted on more numerous, and therefore more reliable, groups of 105 to 1202 patients show an estimated incidence of celiac disease in Down's syndrome patients of $1 \%$ to $6.3 \%[21,24,25,30,32,34$, $41,42,44]$. In the analysis mentioned above the study of Goldacre et al. [41] was a result of a retrospective analysis of medical records of 1453 patients Down's syndrome from the Oxford region from the years 1963-1999. Thus, it was impossible to diagnose all cases of celiac disease, especially in patients with the silent form of the disease.

The published studies about the incidence of celiac disease in Down's syndrome patients utilized different criteria of patient selection (Table II), and thus the study groups are heterogeneous and the results are 
difficult to compare. Most of the studies were conducted on patients under care of a local medical center [22, 30, 31, 35, 36, 38, 42-44]; there are few studies on the incidence of celiac disease in Down's syndrome patients conducted on the scale of a large region or country [32, 39, 40].

The only available multi-center study assessing the incidence of celiac disease, conducted on a group of Down's syndrome patients in a number that complies with the requirements of an epidemiological study, was performed by an Italian group. Bonamico et al. [32] assessed the incidence of celiac disease in Italian Down's syndrome patients at 4.6\%. The study included 1202 persons (1110 children and 92 adults), who remained under the care of pediatric societies from different regions of Italy. The authors applied the current criteria of celiac disease diagnosis according to ESPGHAN 1990. Positive results of serological studies were confirmed by a histopathological examination of biopsy specimens collected by endoscopy. The obtained results indicate higher incidence of celiac disease in Down's syndrome patients than in the general Italian population. However, the multi-center study by Bonamico et al. [32] regards only Italian Down's syndrome patients, and therefore its results cannot be related to Polish patients. So far, no assessment of the incidence of celiac disease in pediatric or adult Down's syndrome patients has been performed in Poland.

\section{Which Down's syndrome patients should be tested for celiac disease?}

Due to the increased incidence of celiac disease in Down's syndrome patients which was reported in the last years, many researchers and organizations recommend screening this group of patients. Though some authors suggest testing of all Down's syndrome patients, regardless of the clinical picture, others claim that the screening for celiac disease in Down's syndrome patients should include only persons who show typical clinical signs $[39,47]$. This approach is supported by the results of some analyses. In the study by Kolek et al. [39] all Down's syndrome patients diagnosed with celiac disease showed symptoms characteristic for celiac disease (loose stool, constipation, discomfort in the abdominal cavity). The authors suggest that screening for celiac disease is justified in patients with symptoms, but not in patients without symptoms. Similarly, in a German study [37], clinical symptoms of celiac disease (diarrhea, abdominal pain, insufficient body weight, flatulence) were observed in all Down's syndrome children who were newly diagnosed with celiac disease.

At the moment of diagnosis of celiac disease, characteristic gastroenterological symptoms are shown by
44-69\% of Down's syndrome children [32-34], whereas a less typical clinical picture (insufficient height, anemia) is observed in $11-39 \%$ [32, 34]. Around $17-50 \%$ of patients show no symptoms $[32,34]$. Compared to the general population, in Down's syndrome children, the symptomatic form of celiac disease is more frequent than asymptomatic forms [32]. It is estimated that the ratio of the incidence of symptomatic and asymptomatic forms of celiac disease in the general population is $1: 8$ [48], whereas in Down's syndrome patients it is $4: 1$ [32], which means that in Down's syndrome patients, celiac disease with full clinical manifestation is more frequent than its asymptomatic forms. It weighs in favor of testing for celiac disease only those Down's syndrome patients who show symptoms of celiac disease.

In the literature, also the financial aspect of screening Down's syndrome patients for celiac disease was brought up. Swigonski et al. [47] analyzed the costs of screening for celiac disease of Down's syndrome patients without symptoms, as a means of prevention of nonHodgkin lymphoma, which is a late complication of celiac disease. Based on estimated data it was concluded that the cost of such screening would greatly exceed the possible benefits from identification of patients with the silent form of the disease, and it would not improve the QALY index (quality-adjusted life year). Therefore, the authors suggest not testing Down's syndrome patients who show no celiac disease symptoms.

Many authors suggest that Down's syndrome patients not showing symptoms of celiac disease should be tested. Book et al. [33] substantiate it by the similar incidence of clinical symptoms suggesting celiac disease in Down's syndrome children who were diagnosed with celiac disease and those who were not. However, the results of their study were not based on reliable diagnostic criteria, since the patients were diagnosed with celiac disease based on serological examinations only (EmA), without histopathological examination.

The recent recommendations, NICE 2009 (National Institute for Health and Clinical Excellence), have placed Down's syndrome among diseases in which serological tests for celiac disease should be considered, such as in the case of Addison's disease, autoimmune liver disorders, autoimmune myocarditis, idiopathic thrombocytopenia, depression, bipolar disorder, epilepsy, lymphoma, constipation, neuropathy, Sjögren's syndrome, Turner syndrome, infertility, and others [49]. In the mentioned cases, these recommendations do not imply testing for celiac disease in all patients with the mentioned disorders, including Down's syndrome [49].

In conclusion, based on the literature data it can be concluded that considering Down's syndrome patients 
as a risk group for celiac disease is not supported by reliable scientific studies. The studies published so far mostly concern relatively small groups of Down's syndrome patients, compared to the very numerous groups examined in epidemiological studies on the incidence of celiac disease in the general population $[6,7,9]$. In the literature, there is only one study, by Italian authors [32], which could meet the mentioned requirements. However, taking into consideration the region-dependent specificity of celiac disease incidence [48], the results of this study cannot be related directly to Polish conditions. Moreover, the variety of celiac disease diagnostic criteria applied by different authors makes the obtained data on the incidence of celiac disease in Down's syndrome patients unreliable, according to current standards, and makes it impossible to draw explicit conclusions. The incidence of celiac disease in children and adults with Down's syndrome is probably higher than the estimated incidence in the general population. However, in order to consider these patients as a risk group, it is necessary to perform reliable epidemiological examinations, including in Poland, which would involve selection of large groups of patients and determination of uniform, currently applied diagnostic criteria.

\section{References}

1. Szaflarska-Popławska A, Popławski C, Müller L, et al. Do oats belong in a gluten-free diet? Pediatr Pol 2005; 80: 1007-10.

2. Szajewska H, Dziechciarz P. Chronic diarrhoea and celiac disease. Med Prakt Pediatr (Special issue) 2008; 1: 83-6.

3. Oberhuber G, Granditsch G, Vogelsang H. The histopathology of coeliac disease: time for a standardized report scheme for pathologists. Eur J Gastroenterol Hepatol 1999; 11: 1185-94.

4. Ribes-Koninckx C, Mearin M, Korponay-Szabó I, et al.; The ESPGHAN Working Group on Coeliac Disease Diagnosis. Coeliac disease diagnosis: ESPGHAN 1990 Criteria or need for a change? Results of a questionnaire. J Pediatr Gastroenterol Nutr 2012; 54: 15-9.

5. Szaflarska-Popławska A, Parzęcka M, Müller L, et al. Screening for celiac disease in Poland. Med Sci Monit 2009; 15: PH 7-11.

6. Dube C, Rostom A, Sy R, et al. The prevalence of celiac disease in average-risk and at-risk Western European populations: a systematic review. Gastroenterology 2005; 128: 57-67.

7. Biagi F, Klersy C, Balduzzi D, et al. Are we not over-estimating the prevalence of coeliac disease in the general population? Ann Med 2010; 42: 557-61.

8. Lohi S, Mustalahti K, Kaukinen K, et al. Increasing prevalence of celiac disease over time. Aliment Pharmacol Ther 2007; 26 1217-25.

9. Mearin ML, Ivarsson A, Dickey W. Coeliac disease: is it time for mass screening? Best Pract Res Clin Gastroenterol 2005; 19: 441-52.

10. Hoffenberg EJ. Should all children be screened for celiac disease? Gastroenterology 2005; 128: 98-103.
11. Catassi C, Rätsch IM, Gandolfi L, et al. Why is coeliac disease endemic in the people of the Sahara? Lancet 1999; 354: 647-8.

12. Szaflarska-Popławska A, Karczewska K, Żabka A, et al. Incidence of celiac disease in Poland - multicenter study. Pediatr Współcz Gastroenterol Hepatol Żyw Dz 2009; 11: 111-6.

13. Szaflarska-Popławska A. Etiopathogenesis of celiac disease. Pediatr Współcz 2009; 11: 83-6.

14. Kondrashova A, Mustalahti K, Kaukinen K. Lower economic status and inferior hygienic environment may protect against celiac disease. Ann Med 2008; 40: 223-31.

15. Henker J, Losel A, Conrad K, et al. Prevalence of asymptomatic coeliac disease in children and adults in the Dresden region of Germany. Deutsch Med Wochenschr 2002; 127: 1511-5.

16. Ivarsson A, Persson LA, Nystrom L, et al. Epidemic of celiac disease in Swedish children. Acta Paediatr 2000; 89: 165-71.

17. Myléus A, Ivarsson A, Webb C, et al. Celiac disease revealed in $3 \%$ of Swedish 12-year-olds born during an epidemic. J Pediatr Gastroenteol Nutr 2009; 49: 170-6.

18. Bentley DA. A case of Down's syndrome complicated by retinoblastoma and coeliac disease. Pediatrics 1975; 56: 131.

19. Dias JA, Walker-Smith J. Down's syndrome and celiac disease. J Pediatr Gastroenterol Nutr 1990; 10: 41-3.

20. Granditsch G, Rossipal E. Down's syndrome and celiac disease. J Pediatr Gastroenterol Nutr 1990; 11: 279.

21. Castro M, Crino A, Papadatou B, et al. Down's syndrome and celiac disease: the prevalence of high IgA-antigliadin antibodies and HLA-DR and DQ antigens in Trisomy 21. J Pediatr Gastroenterol Nutr 1993; 16: 265-8.

22. Zubillaga P, Vitoria JC, Arrieta A, et al. Down's syndrome and celiac disease. J Pediatr Gastroenterol Nutr 1993; 16: 168-71.

23. Jansson U, Johansson C. Down syndrome and celiac disease. J Pediatr Gastroenterol Nutr 1995; 21: 443-5.

24. Mearin ML, George EK, Bouquet J, et al. How should we screen for celiac disease in Down's syndrome? Neth J Med 1995; 47: A39-40.

25. Bonamico M, Rasore-Quartino A, Mariani P, et al. Down syndrome and coeliac disease: usefulness of antigliadin and antiendomysium antibodies. Acta Paediatr 1996; 85: 1503-5.

26. Failla P, Ruberto C, Pagano MC, et al. Celiac disease in Down's syndrome with HLA serological and molecular studies. J Pediatr Gastroenterol Nutr 1996; 23: 303-6.

27. George EK, Mearin ML, Bouquet J, et al. High frequency of celiac disease in Down syndrome. J Pediatr 1996; 128: 555-7.

28. Gale L, Wimalaratna H, Brotodiharjo A, et al. Down's syndrome is strongly associated with celiac disease. Gut 1997; 40: 492-6.

29. Carlsson A, Axelsson I, Borulf S, et al. Prevalence of IgA-antigliadin antibodies and IgA-antiendomysium antibodies related to celiac disease in children with Down syndrome. Pediatrics 1998; 101: 272-5.

30. Pueschel SM, Romano C, Failla P, et al. A prevalence study of celiac disease in persons with Down syndrome residing in the United States of America. Acta Paediatr 1999; 88: 953-6.

31. Zachor DA, Mroczek-Musulman E, Brown P. Prevalence of celiac disease in Down syndrome in the United States. J Pediatr Gastroenterol Nutr 2000; 31: 275-9.

32. Bonamico M, Mariani P, Danesi HM, et al. Prevalence and clinical picture of celiac disease in Italian Down syndrome pa- 
tients: a multicenter study. J Pediatr Gastroenterol Nutr 2001; 33: 139-43.

33. Book L, Hart A, Black J, et al. Prevalence and clinical characteristics of celiac disease in Downs syndrome in a US study. Am J Med Genet 2001; 98: 70-4.

34. Carnicer J, Farre C, Varea V, et al. Prevalence of coeliac disease in Down's syndrome. Eur J Gastroenterol Hepatol 2001; 13: 263-7.

35. Mackey J, Treem WR, Worley G, et al. Frequency of celiac disease in individuals with Down syndrome in the United States. Clin Pediatr 2001; 40: 249-52.

36. Rumbo M, Chirdo FG, Ben R, et al. Evaluation of coeliac disease serological markers in Down syndrome patients. Dig Liv Dis 2002; 34: 116-21.

37. Sanchez-Albisua I, Storm W, Wäscher I, et al. How frequent is celiac disease in Down syndrome? Eur J Pediatr 2002; 161 683-4.

38. Cogulu O, Ozkinay F, Gunduz C, et al. Celiac disease in children with Down syndrome: Importance of follow-up and serologic screening. Pediatr Int 2003; 45: 395-9.

39. Kolek A, Vospelova J, Hermenova Z, et al. Occurrence of coeliac disease in children with Down's syndrome in north Moravia, Czech Republic. Eur J Pediatr 2003; 162: 207-8.

40. Sciberras C, Vella C, Grech V. The prevalence of celiac disease in Down's syndrome in Malta. Ann Trop Paediatr 2004; 24: 81-3.

41. Goldacre MJ, Wotton CJ, Seagroatt V, et al. Cancers and immune related diseases associated with Down's syndrome: a record linkage study. Arch Dis Child 2004; 89: 1014-7.

42. Alanay Y, Boduroglu K, Tuncbilek E. Celiac disease screening in 100 Turkish children with Down syndrome. Turk J Pediatr 2005; 47: $138-40$.

43. Nisihara RM, Kotze LMS, Utiyama SRR, et al. Celiac disease in children and adolescents with Down syndrome. J Pediatr 2005; 81: 373-6.

44. Uibo O, Teesalu K, Metskula K, et al. Screening for celiac disease in Down's syndrome patients revealed cases of subtotal villous atrophy without typical for celiac disease HLA-DQ and tissue transglutaminase antibodies. World J Gastroenterol 2006; 12: 1430-4.

45. Cerqueira RM, Rocha CM, Fernandes CD, et al. Celiac disease in Portuguese children and adults with Down syndrome. Eur J Gastroenterol Hepatol 2010; 22: 868-71.

46. Pavlovic M, Radlovic N, Lekovic Z, et al. When to screen children with Down syndrome for celiac disease? J Trop Pediatr 2010; 56: 443-5.

47. Swigonski NL, Kuhlenschmidt HL, Bull MJ, et al. Screening for celiac disease in asymptomatic children with Down syndrome: cost-effectiveness of preventing lymphoma. Pediatrics 2006; 118: 594-602.

48. Catassi C, Fabiani E, Ratsch IM, et al. The coeliac iceberg in Italy. A multicentre antigliadin antibodies screening for coeliac disease in school-age subjects. Acta Paediatr Suppl 1996; 412 29-35.

49. National Institute for Health and Clinical Excellence. Coeliac disease: recognition and assessment of coeliac disease. NICE clinical guideline 86. London: NICE, 2009. 